\title{
The top 100 cited articles in urology
}

\author{
Kiara Hennessey, MD; Kourosh Afshar, MHSc, MD, FRCSC, FAAP; Andrew E. MacNeily, MD, FRCSC, FAAP
}

See related article on page 303

\section{Abstract}

Background: We identified and analyzed the characteristics of the 100 most frequently cited articles published between 1965 and 2007 in journals pertaining to urology and related fields.

Methods: We selected 69 of the highest impact urology and subspecialty journals and 22 of the highest impact general medical and medical research journals from the 2006 edition of Journal Citation Reports: Science edition. We identified the 100 most frequently cited urological articles published in these 91 journals using the Science Citation Index Expanded (1965-present). We reviewed and analyzed the articles.

Results: The top 100 articles were cited a mean of 629 times (range 418-1435) and published between 1965 and 2003, with $89 \%$ published after 1979 and $54 \%$ published in the 1990s. Fifteen journals were represented, led by The New England Journal of Medicine (30), The Journal of Urology (22) and Lancet (11). Ninety publications originated from North America (81) or the United Kingdom (9). Johns Hopkins University (13), Harvard University (5), Stanford University (5) and University of California, Los Angeles (5) published the most articles. Five urologists were first authors of 2 or more of the articles. Fifty-six articles reported observational studies. Oncology (51) and transplantation (20) were the most commonly represented urological subfields.

Conclusion: These top-cited articles in urology identify topics and authors that contributed to major advances in urology. Observational studies and randomized controlled trials in oncology published in high-impact urological or medical journals constitute the most common type of highly cited publications.

Can Urol Assoc J 2009;3(4):293-302

\section{Résumé}

Renseignements généraux : Nous avons dégagé et analysé les caractéristiques des 100 articles les plus souvent cités publiés dans des périodiques spécialisés en urologie et dans les domaines connexes entre 1965 et 2007.

Méthodologie : Soixante-neuf des périodiques les plus influents en urologie et dans les domaines connexes et 22 des périodiques les plus influents en médecine générale et en recherche médicale ont été choisis à partir du Journal Citation Reports: Science Edition de
2006. Les 100 articles les plus souvent cités dans le domaine de I'urologie ayant paru dans ces 91 périodiques ont été dégagés à partir du Science Citation Index Expanded (de 1965 à aujourd'hui). Les articles ont été passés en revue et analysés.

Résultats : Les 100 principaux articles ont été cités en moyenne 629 fois (écart : 418 à 1435) et publiés entre 1965 et 2003; $89 \%$ ont été publiés après 1979 et 54 \%, dans les années 90. Quinze périodiques étaient représentés, avec en tête le New England Journal of Medicine (30), le Journal of Urology (22) et Lancet (11). Quatre-vingt-dix périodiques étaient publiés en Amérique du Nord (81) ou au Royaume-Uni (9). Johns Hopkins (13), Harvard (5), Stanford (5), et l'Université de la Californie à Los Angeles (5) sont les universités qui ont publié le plus d'articles. Cinq urologues étaient les premiers auteurs de plus de 2 articles. Cinquante-six articles signalaient les résultats d'études observationnelles. L'oncologie (51) et les transplantations (20) étaient les sousdomaines les plus souvent représentés.

Conclusion : Ces articles les plus cités en urologie permettent de cerner les auteurs et les sujets qui se trouvent au cœur des principales percées dans le domaine de l'urologie. Les études observationnelles et les études contrôlées avec randomisation publiées dans les périodiques influents traitant d'urologie ou de médecine générale constituent le type le plus fréquemment observé parmi les articles les plus souvent cités.

\section{Introduction}

Citation analysis is the field of bibliometrics that examines the citation relationships between authors or their work. ${ }^{1}$ The number of times that articles are referenced in other articles is widely used to measure the impact an article or individual researcher has on the scientific community. It is often seen as a direct measure of the recognition that work has warranted in its scientific field. In some circumstances, this number is also viewed as a measure of quality. ${ }^{2}$ However, there is considerable debate regarding the value of citation rates when used to assess the quality of research. ${ }^{2}$

Recently, various specialties have attempted to identify and analyze the "citation classics" in their field..$^{2-4}$ In addition, several journals have published their own citation classics. ${ }^{5,6}$ To date, a comprehensive list of the top-cited articles in the field of urology is not available. 
The purpose of this study was to identify and analyze the characteristics of the 100 most frequently cited articles published in journals dedicated to urology and its related fields.

\section{Methods}

We selected 63 of the highest impact journals dedicated to urology and its subspecialty areas and 22 of the highest impact general medical and medical research journals from the 2006 edition of Journal Citation Reports [JCR]: Science edition (Box 1). The impact factor of journals is calculated based on a 2-year period. It can be viewed as the mean number of citations in a year given to those papers in a journal that were published during the 2 preceding years. We found the 63 urology and subspecialty journals under the subject categories "Urology \& Nephrology" and "Transplantation" in the JCR 2006. We included all journals except 4 nephrology journals and 5 transplant journals because they did not pertain to urology. We selected the 22 general medical and medical research journals by searching the JCR 2006 subject categories "Medicine, General \& Internal" and "Medicine Research \& Experimental." We then ranked the journals in these subject categories by impact factor. We included all journals whose top-cited articles received greater than 10 citations.

To be as comprehensive as possible, we attempted to identify any further urological journals in existence. Employing an internet search for [urology journals] via the search engine Google yielded an additional 2 urological journals, Urologic Radiology and Urologic Oncology. We then cross-referenced this new compiled list of 87 journals with the list of journals searched in the textbook Classic Papers in Urology ${ }^{\top}$ and subsequently included 4 additional urological journals. In total, we searched 91 journals (69 urological/subspecialty, 22 medical/research).

We identified the 100 most frequently cited urological articles from the 91 journals using the database of the Science Citation Index Expanded (1965-present). ${ }^{8}$ This database includes publications from the 42-year period 19652007. We searched each of the 91 journals using the database and we included every article that received greater than 100 citations in a comprehensive ranked list. The top 100 articles from this list made up our final list of the top 100 cited articles in urology. We accessed and reviewed the articles online using MEDLINE. When relevant information was unavailable online, we obtained the articles in print format. We analyzed the articles and tabulated the data according to the following predefined parameters: number of citations, year of publication, country of origin, institution, journal, type of article, subfield of urology and authorship.

\section{Results}

The top 100 cited articles are listed in Table 1 in descending order, according to the number of citations they received. The mean number of citations per article was 629 (range 418-1435). The top 100 cited articles were published between 1965 and 2003. The oldest article was published in 1965 (Stamey et al., Medicine, 1965) and the most recent article in 2003 (Yang et al., New England Journal of Medicine, 2003). Overall, 89\% of the articles were published after 1979.

The 100 articles originated from 12 countries (Table 2). Twelve institutions published 2 or more of the top-cited articles (Table 3). Five investigators were first authors of 2 or more of the top-cited articles (Table 4).

Despite the fact that we searched 91 high-impact journals, only $15(16 \%)$ of these journals were represented by the top 100 articles (Table 5). Table 6 depicts the types of studies that constitute the top-cited articles. A total of 56 (56\%) were observational studies. Oncology (51, 51\%) and transplantation $(20,20 \%)$ were the most commonly represented subspecialties (Table 7).

\section{Discussion}

Analysis of most frequently cited articles and the journals in which they appear serves several purposes. It identifies and emphasizes the impact of the work of our colleagues and predecessors, recognizes key advances in urology and adds useful perspective on historical developments in our specialty. ${ }^{3}$ Use of citation analysis to examine the urological literature also reveals quantitative information about authors, topics and journals that is helpful in identifying classic works and high-impact journals. ${ }^{3}$

Although it is not possible to provide a detailed analysis of all 100 articles, some interesting observations can be made about the top 10. These reflect major advances in urology and a number of "hot topics" over the years. Three of the top 10 articles represent the monumental contribution of prostate-specific antigen (PSA) and gleason grading to the investigation and management of prostate cancer. At position 2, Stamey and colleagues describe PSA as a serum marker for prostate cancer in 1987. At position 5, Catalona and coauthors introduce PSA as a screening test for prostate cancer in 1991, and at position 9, Gleason and Mellinge describe the combination of histological grading with clinical stage to predict prostate cancer prognosis in 1974. Other major advances in the treatment of urological diseases are represented by Einhorn and Donohue in 1977 at position 3, with treatment of disseminated testicular cancer using cisplatinum-based chemotherapy; Palermo and coworkers in 


\section{Box 1. Journals selected for screening}

Urology and subspecialty journals

Advances in Chronic Kidney Disease

Advances in Renal Replacement Therapy

Aktuelle Urologie

American Journal of Kidney Diseases

American Journal of Nephrology

American Journal of Physiology — Renal Physiology

American Journal of Transplantation

Annales d'Urologie

Artificial Organs

ASAIO Journal

Asian Journal of Andrology

BJU International

Blood Purification

Cell Transplantation

Clinical Nephrology

Clinical Transplantation

Contributions to Nephrology

Current Opinion in Nephrology and Hypertension

Current Opinion in Urology

Dialysis \& Transplantation

European Urology

European Urology Supplements

Infections in Urology

International Journal of Artificial Organs

International Journal of Impotence Research

International Journal of Urology

International Urogynecology Journal

International Urology and Nephrology

Journal d'Urologie et de Nephrologie

Journal of Endourology

Journal of Nephrology

Journal of Renal Nutrition

Journal of Sexual Medicine

Journal of the American Society of Nephrology

Journal of Urology

Kidney and Blood Pressure Research

Kidney International

Molecular Urology

Nature Clinical Practice Urology

Nefrologia

Nephrology

Nephrology Dialysis Transplantation

Neurourology and Urodynamics

Pediatric Nephrology

Pediatric Transplantation
Peritoneal Dialysis International

Progres en Urologie

Prostate

Prostate Cancer and Prostatic Diseases

Renal Failure

Scandinavian Journal of Urology and Nephrology

Seminars in Dialysis

Seminars in Nephrology

Therapeutic Apheresis and Dialysis

Transplantation

Transplantation Proceedings

Transplant Immunology

Transplant International

Urologia Internationalis

Urologic Clinics of North America

Urologic Oncology

Urologic Oncology: Seminars and Original Investigations

Urologic Radiology

Urological Research

Urological Survey

Urologe

Urology

World Journal of Urology

Xenotransplantation

General medical and medical research journals

American Journal of Medicine

American Journal of Preventive Medicine

Annals of Family Medicine

Annals of Internal Medicine

Annals of Medicine

Annual Review of Medicine

Archives of Internal Medicine

BMJ

Canadian Medical Association Journal

Current Medical Research and Opinion

European Journal of Clinical Investigation

Journal of General Internal Medicine

Journal of Internal Medicine

Journal of the American Medical Association

Lancet

Mayo Clinic Proceedings

Medicine

Nature

New England Journal of Medicine

PLoS Medicine

QJM: An International Journal of Medicine

Science 
Hennessey et al.

Table 1. The top 100 cited articles in urology (part 1 of 4)

\begin{tabular}{|c|c|c|}
\hline Rating & Article & $\begin{array}{l}\text { No. of } \\
\text { citations }\end{array}$ \\
\hline 1 & $\begin{array}{l}\text { Feldman HA, Goldstein I, Hatzichristou DG, et al. Impotence and its medical and psychosocial correlates: } \\
\text { results of the Massachusetts Male Aging Study. J Urol 1994;151:54-61. }\end{array}$ & 1435 \\
\hline 2 & $\begin{array}{l}\text { Stamey TA, Yang N, Hay AR, et al. Pros tate-specific antigen as a serum marker for adenocarcinoma of the } \\
\text { prostate. N Engl J Med 1987;317:909-16. }\end{array}$ & 1250 \\
\hline 3 & $\begin{array}{l}\text { Einhorn LH, Donohue J. Cis-diamminedichloroplatinum, vinblastine, and bleomycin combination } \\
\text { chemotherapy in disseminated testicular cancer. Ann Intern Med 1977;87:293-8. }\end{array}$ & 1209 \\
\hline 4 & $\begin{array}{l}\text { Palermo G, Joris H, Devroey P, et al. Pregnancies after intracytoplasmic injection of single spermatozoon } \\
\text { into an oocyte. Lancet 1992;340:17-8. }\end{array}$ & 1122 \\
\hline 5 & $\begin{array}{l}\text { Catalona WJ, Smith DS, Ratliff TL, et al. Measurment of prostate-specific antigen in serum as a screening- } \\
\text { test for prostate-cancer. N Engl J Med } 1991 ; 324: 1156-61 \text {. }\end{array}$ & 1052 \\
\hline 6 & $\begin{array}{l}\text { Goldstein I, Lue TF, Padma-Nathan H, et al. Oral sildenafil in the treatment of erectile dysfunction. N Engl J } \\
\text { Med 1998;338:1397-404. }\end{array}$ & 973 \\
\hline 7 & $\begin{array}{l}\text { Racusen LC, Solez K, Colvin RB, et al. The Banff } 97 \text { working classification of renal allograft pathology. } \\
\text { Kidney Int 1999;55:713-23. }\end{array}$ & 957 \\
\hline 8 & $\begin{array}{l}\text { Barry MJ, Fowler FJ, Oleary MP, et al. The American Urological Association symptom index for benign } \\
\text { prostatic hyperplasia. J Urol 1992;148:1549-57. }\end{array}$ & 942 \\
\hline 9 & $\begin{array}{l}\text { Gleason DF, Mellinge GT. Prediciton of prognosis for prostatic adenocarcinoma by combined histological } \\
\text { grading and clinical staging. J Urol 1974;111:58-64. }\end{array}$ & 924 \\
\hline 10 & $\begin{array}{l}\text { Sharpe RM, Skakkebaek NE. Are estrogens involved in falling sperm counts and disorders of the male } \\
\text { reproductive tract. Lancet 1993;341:1392-5. }\end{array}$ & 910 \\
\hline 11 & $\begin{array}{l}\text { Rosen RC, Riley A, Wagner G, et al. The international index of erectile function (IIEF): a multidimensional } \\
\text { scale for assessment of erectile dysfunction. Urology 1997;49:822-30. }\end{array}$ & 901 \\
\hline 12 & $\begin{array}{l}\text { Chan JM, Stampfer MJ, Giovannucci E, et al. Plasma insulin-like growth factor I and prostate cancer risk: a } \\
\text { prospective study. Science 1998;279:563-6. }\end{array}$ & 901 \\
\hline 13 & $\begin{array}{l}\text { Oesterling JE. Prostate specific antigen: a critical assessment of the most useful tumor-marker for } \\
\text { adenocarcinoma of the prostate. } J \text { Urol 1991;145:907-23. }\end{array}$ & 877 \\
\hline 14 & $\begin{array}{l}\text { Crawford ED, Eisenberger MA, Mcleod DG, et al. A controlled trial of leuprolide with and without flutamide } \\
\text { in prostatic-carcinoma. N Engl J Med 1989;321:419-24. }\end{array}$ & 870 \\
\hline 15 & $\begin{array}{l}\text { Solez K, Axelsen RA, Benediktsson } \mathrm{H} \text {, et al. International standardization of criteria for the histologic } \\
\text { diagnosis of renal-allograft rejection: the Banff working classification of kidney transplant pathology. Kidney } \\
\text { Int 1993;44:411-22. }\end{array}$ & 862 \\
\hline 16 & $\begin{array}{l}\text { Calne RY, Pentlow BD, White DJG, et al. Cyclosporin-A in patients receiving renal allografts from cadaver } \\
\text { donors. Lancet 1978;2:1323-7. }\end{array}$ & 850 \\
\hline 17 & $\begin{array}{l}\text { Carlsen E, Giwercman A, Keiding N, et al. Evidence for decreasing quality of semen during past } 50 \text { years. } \\
\text { BMJ 1992;305:609-13. }\end{array}$ & 849 \\
\hline 18 & $\begin{array}{l}\text { Robson CJ, Churchil BM, Anderson W. Results of radical nephrectomy for renal cell carcinoma. J Urol } \\
\text { 1969;101:297-301. }\end{array}$ & 845 \\
\hline 19 & $\begin{array}{l}\text { Opelz G, Sengar DPS, Mickey MR, et al. Effect of blood transfusions on subsequent kidney transplants. } \\
\text { Transplant Proc 1973;5:253-9. }\end{array}$ & 839 \\
\hline 20 & Loehrer PJ, Einhorn LH. Drugs 5 years later: Cisplatin. Ann Intern Med 1984;100:704-13. & 828 \\
\hline 21 & $\begin{array}{l}\text { Gabrilove JL, Jakubowski A, Scher H, et al. Effect of granulocyte colony-stimulating factor on neutropenia } \\
\text { and associated morbidity due to chemotherapy for transitional-cell carcinoma of the urothelium. } N \text { Engl J } \\
\text { Med 1988;318:1414-22. }\end{array}$ & 826 \\
\hline 22 & $\begin{array}{l}\text { Sollinger HW. Mycophenalate mofetil for the prevention of acute rejection in primary cadaveric renal } \\
\text { allograft recipients. Transplantation 1995;60:225-32. }\end{array}$ & 803 \\
\hline 23 & $\begin{array}{l}\text { Mebust WK, Holtgrewe HL, Cockett ATK, et al. Transurethral prostatectomy: immediate and postoperative } \\
\text { complications: a cooperative study of } 13 \text { participating institutions evaluating } 3883 \text { patients. J Urol } \\
\text { 1989;141:243-7. }\end{array}$ & 784 \\
\hline 24 & $\begin{array}{l}\text { Pound CR, Partin AW, Eisenberger MA, et al. Natural history of progression after PSA elevation following } \\
\text { radical prostatectomy. JAMA 1999;281:1591-7. }\end{array}$ & 774 \\
\hline 25 & Droller MJ, Anderson JR, Beck JC, et al. Impotence. JAMA 1993;270:83-90. & 761 \\
\hline \multicolumn{3}{|c|}{ Continued on next page } \\
\hline
\end{tabular}




\section{Table 1. The top 100 cited articles in urology (part 2 of 4)}

\begin{tabular}{|c|c|c|}
\hline Rating & Article & $\begin{array}{l}\text { No. of } \\
\text { citations }\end{array}$ \\
\hline 26 & Belzer FO, Southard JH. Prinicples of solid organ preservation by cold storage. Transplantation 1988;45:673-6. & 759 \\
\hline 27 & $\begin{array}{l}\text { Partin AW, Kattan MW, Subong ENP, et al. Combination of prostate-specific antigen, clinical stage, and } \\
\text { gleason score to predict pathological stage of localized prostate cancer: a multi-institutional update. JAMA } \\
\text { 1997;277:1445-51. }\end{array}$ & 755 \\
\hline 28 & $\begin{array}{l}\text { Berry SJ, Coffey DS, Walsh PC, et al. The development of human benign prostatic hyperplasia with age. } \\
\text { J Urol 1984;132:474-9. }\end{array}$ & 751 \\
\hline 29 & Starzl TE, Todo S, Fung J, et al. FK-506 for liver, kidney, and pancreas transplantation. Lancet 1989;2:1000-4. & 721 \\
\hline 30 & $\begin{array}{l}\text { Abrams P, Cardozo L, Fall M, et al. The standardisation of terminology of lower urinary tract function: report } \\
\text { from the Standardisation Sub-Committee of the International Continence Society. Neurourol Urodyn } \\
2002 ; 21: 167-78 .\end{array}$ & 716 \\
\hline 31 & $\begin{array}{l}\text { Sidransky D, Voneschenbach A, Tsai YC, et al. Indentification of P53 gene-mutations in bladder cancers and } \\
\text { urine samples. Science 1991;252:706-9. }\end{array}$ & 709 \\
\hline 32 & $\begin{array}{l}\text { Bolla M, Gonzalez D, Warde P, et al. Improved survival in patients with locally advanced prostate cancer } \\
\text { treated with radiotherapy and goserelin. N Engl J Med 1997;337:295-300. }\end{array}$ & 683 \\
\hline 33 & $\begin{array}{l}\text { Hariharan S, Johnson CP, Bresnahan BA, et al. Improved graft survival after renal transplantation in the } \\
\text { United States, } 1988 \text { to 1996. N Engl J Med 2000;342:605-12. }\end{array}$ & 665 \\
\hline 34 & $\begin{array}{l}\text { Cohen DJ, Loertscher R, Rubin MF, et al. Cyclosporine: a new immunosuppressive agent for organ } \\
\text { transplantation. Ann Intern Med 1984;101:667-82. }\end{array}$ & 663 \\
\hline 35 & $\begin{array}{l}\text { Oesterling JE, Jacobsen SJ, Chute CG, et al. Serum prostate-specific antigen in a community-based } \\
\text { population of healthy men: establishment of age-specific reference ranges. JAMA 1993;270:860-4. }\end{array}$ & 658 \\
\hline 36 & $\begin{array}{l}\text { Catalona WJ, Richie JP, Ahmann FR, et al. Comparison of digital rectal examination and serum prostate- } \\
\text { specific antigen in the early detection of prostate cancer: results of a multicenter clinical trial of } 6630 \text { men. } \\
J \text { Urol 1994;151:1283-90. }\end{array}$ & 657 \\
\hline 37 & $\begin{array}{l}\text { Williams SD, Birch R, Einhorn LH, et al. Treatment of disseminated germ-cell tumors with cisplatin, } \\
\text { bleomycin, and either vinblastine or etoposide. N Engl J Med 1987;316:1435-40. }\end{array}$ & 653 \\
\hline 38 & $\begin{array}{l}\text { Gormley GJ, Stoner E, Bruskewitz RC, et al. The effect of finasteride in men with benign prostatic } \\
\text { hyperplasia. N Engl J Med 1992;327:1185-91. }\end{array}$ & 629 \\
\hline 39 & $\begin{array}{l}\text { Grinyo J, Groth C, Pichlmyer R, et al. Placebo-controlled study of mycophenolate mofetil combined with } \\
\text { cyclosporine and corticosteroids for prevention of acute rejection. Lancet 1995;345:1321-5. }\end{array}$ & 619 \\
\hline 40 & $\begin{array}{l}\text { Hricik DE, Browning PJ, Kopelman R, et al. Captopril-induced functional renal-insufficiency in patients with } \\
\text { bilateral renal-artery stenoses or renal-artery stenosis in a solitary kidney. N Engl J Med 1983;308:373-6. }\end{array}$ & 608 \\
\hline 41 & $\begin{array}{l}\text { Cosimi } A B \text {, Colvin RB, Burton } \mathrm{RC} \text {, et al. Use of monoclonal antibodies to T-cell subsets for immunological } \\
\text { monitoring and treatment in recipients of renal allografts. N Engl J Med 1981;305:308-14. }\end{array}$ & 606 \\
\hline 42 & $\begin{array}{l}\text { Partin AW, Yoo J, Carter HB, et al. The use of prostate-specific antigen, clinical stage and gleason score to } \\
\text { predict pathological stage in men with localized prostate cancer. J Urol 1993;150:110-4. }\end{array}$ & 594 \\
\hline 43 & $\begin{array}{l}\text { Pirsch JD, Miller J, Deierhoi MH, et al. A comparison of tacrolimus (FK506) and cyclosporine for } \\
\text { immunosuppression after cadaveric renal transplantation. Transplantation 1997;63:977-83. }\end{array}$ & 589 \\
\hline 44 & $\begin{array}{l}\text { Bookstein R, Shew JY, Chen PL, et al. Suppression of tumorigenicity of human prostate carcinoma cells by } \\
\text { replacing a mutated RB gene. Science 1990;247:712-5. }\end{array}$ & 587 \\
\hline 45 & $\begin{array}{l}\text { Wolfe RA, Ashby VB, Milford EL, et al. Comparison of mortality in all patients on dialysis, patients on dialysis } \\
\text { awaiting transplantation, and recipients of a first cadaveric transplant. N Eng/ J Med 1999;341:1725-30. }\end{array}$ & 584 \\
\hline 46 & $\begin{array}{l}\text { Carter HB, Pearson JD, Metter J, et al. Longitudinal evaluation of prostate-specific antigen levels in men } \\
\text { with and without prostate disease. JAMA 1992;267:2215-20. }\end{array}$ & 581 \\
\hline 47 & $\begin{array}{l}\text { Catalona WJ, Smith DS, Ratliff TL, et al. Detection of organ-confined prostate cancer is increased through } \\
\text { prostate-specific antigen-based screening. JAMA 1993;270:948-54. }\end{array}$ & 579 \\
\hline 48 & $\begin{array}{l}\text { Chodak GW, Thisted RA, Gerber GS, et al. Results of conservative management of clinically localized } \\
\text { prostate cancer. N Engl J Med 1994;330:242-8. }\end{array}$ & 576 \\
\hline 49 & $\begin{array}{l}\text { Keown } \mathrm{P} \text {, Hayry } \mathrm{P} \text {, Mathew T, et al. A blinded, randomized clinical trial of mycophenolate mofetil for the } \\
\text { prevention of acute rejection in cadaveric renal transplantation. Transplantation 1996;61:1029-37. }\end{array}$ & 574 \\
\hline
\end{tabular}


Hennessey et al.

Table 1. The top 100 cited articles in urology (part 3 of 4)

\begin{tabular}{|c|c|c|}
\hline Rating & Article & $\begin{array}{l}\text { No. of } \\
\text { citations }\end{array}$ \\
\hline 50 & $\begin{array}{l}\text { Heney NM, Ahmed S, Flanagan MJ, et al. Superficial bladder cancer progression and recurrence. J Urol } \\
\text { 1983;130:1083-6. }\end{array}$ & 562 \\
\hline 51 & $\begin{array}{l}\text { Walsh PC, Donker PJ. Impotence following radical prostatectomy: insight into etiology and prevention. } \\
\text { J Urol 1982;128:492-7. }\end{array}$ & 561 \\
\hline 52 & $\begin{array}{l}\text { Morales A, Eidinger D, Bruce AW. Intracavitary bacillus calmette-guerin in treatment of superficial bladder } \\
\text { tumors. J Urol 1976;116:180-3. }\end{array}$ & 557 \\
\hline 53 & $\begin{array}{l}\text { Cohen AJ, Li FP, Berg S, et al. Hereditary renal-cell carcinoma associated with a chromosomal translocation. } \\
\text { N Engl J Med 1979;301:592-5. }\end{array}$ & 551 \\
\hline 54 & $\begin{array}{l}\text { Clayman RV, Kavoussi LR, Soper NJ, et al. Laparoscopic nephrectomy: initial case report. J Urol } \\
1991 ; 146: 278-82 .\end{array}$ & 537 \\
\hline 55 & $\begin{array}{l}\text { Hodge KK, McNeal JE, Terris MK, et al. Random systematic versus directed ultrasound guided transrectal } \\
\text { core biopsies of the prostate. J Urol 1989;142:71-5. }\end{array}$ & 524 \\
\hline 56 & $\begin{array}{l}\text { Rajfer J, Aronson WJ, Bush PA, et al. Nitric-oxide as a mediator of relaxation of the corpus cavernosum in } \\
\text { response to nonadrenergic, nonchlolinergic neurotransmission. N Engl J Med 1992;326:90-4. }\end{array}$ & 523 \\
\hline 57 & $\begin{array}{l}\text { Patel R, Terasaki PI. Significance of positive crossmatch test in kidney transplantation. N Engl J Med } \\
\text { 1969;280:735-9. }\end{array}$ & 519 \\
\hline 58 & $\begin{array}{l}\text { Yang JC, Haworth L, Sherry RM, et al. A randomized trial of bevacizumab, an antivascular endothelial } \\
\text { growth factor antibody, for metastatic renal cancer. N Engl J Med 2003;349:427-34. }\end{array}$ & 516 \\
\hline 59 & Rayman MP. The importance of selenium to human health. Lancet 2000;356:233-41. & 514 \\
\hline 60 & Chajek T, Fainaru M. Behçets disease: report of 41 cases and a review of literature. Medicine 1975;54:179-96 & 512 \\
\hline 61 & $\begin{array}{l}\text { Litwin MS, Hays RD, Fink A, et al. Quality-of-life outcomes in men for localized prostate cancer. JAMA } \\
\text { 1995;273:129-35. }\end{array}$ & 504 \\
\hline 62 & $\begin{array}{l}\text { Childs R, Chernoff A, Contentin N, et al. Regression of metastatic renal-cell carcinoma after } \\
\text { nonmyeloablative allogeneic peripheral-blood stem-cell transplantation. N Engl J Med 2000;343:750-8. }\end{array}$ & 503 \\
\hline 63 & $\begin{array}{l}\text { Almond PS, Matas A, Gillingham K, et al. Risk-factors for chronic rejection in renal allograft recipients. } \\
\text { Transplantation 1993;55:752-7. }\end{array}$ & 502 \\
\hline 64 & Thomas TM, Plymat KR, Blannin J, et al. Prevalence of urinary incontinence. BMJ 1980;281:1243-5. & 499 \\
\hline 65 & $\begin{array}{l}\text { Neal DE, Bennett MK, Hall RR, et al. Epidermal growth factor receptors in human bladder cancer: } \\
\text { comparison of invasive and superficial tumors. Lancet 1985;1:366-8. }\end{array}$ & 498 \\
\hline 66 & $\begin{array}{l}\text { Cooner WH, Mosley BR, Rutherford CL, et al. Pros tate cancer detection in a clinical urological practice by } \\
\text { ultrasonography, digital rectal examination and prostate specific antigen. J Urol 1990;143:1146-54. }\end{array}$ & 487 \\
\hline 67 & $\begin{array}{l}\text { Taplin ME, Bubley GJ, Shuster TD, et al. Mutation of the androgen receptor gene in metastatic androgen- } \\
\text { independent prostate cancer. N Engl J Med 1995;332:1393-8. }\end{array}$ & 481 \\
\hline 68 & $\begin{array}{l}\text { Legha SS, Benjamin RS, Mackay B, et al. Reduction of doxorubicin cardiotoxicity by prolonged continuous } \\
\text { intravenous infusion. Ann Intern Med 1982;96:133-9. }\end{array}$ & 481 \\
\hline 69 & $\begin{array}{l}\text { Stamey TA, Kabalin JN, McNeal JE, et al. Prostate specific antigen in the diagnosis and treatment of } \\
\text { adenocarcinoma of the prostate. II. Radical prostatectomy treated patients. J Uro/ 1989;141:1076-83. }\end{array}$ & 479 \\
\hline 70 & $\begin{array}{l}\text { Epstein JI, Walsh PC, Carmichael M, et al. Pathological and clinical findings to predict tumor extent of } \\
\text { nonpalpable (stage-t1c) prostate-cancer. JAMA 1994;271:368-74. }\end{array}$ & 475 \\
\hline 71 & $\begin{array}{l}\text { Cartwright RA, Rogers HJ, Barhamhall D, et al. Role of n-acetyltransferase phenotypes in bladder } \\
\text { carcinogenesis: a pharmacogenetic epidemiological approach to bladder cancer. Lancet 1982;2:842-6. }\end{array}$ & 474 \\
\hline 72 & Motzer RJ, Bander NH, Nanus DM. Renal-cell carcinoma. N Engl J Med 1996;335:865-75. & 472 \\
\hline 73 & $\begin{array}{l}\text { Christensson A, Bjork T, Nilsson O, et al. Serum prostate-specific antigen complexed to alpha- } \\
\text { 10antichymotrypsin as an indicatior of prostate cancer. J Urol 1993;150:100-5. }\end{array}$ & 463 \\
\hline 74 & $\begin{array}{l}\text { Messing EM, Manola J, Sarosdy M, et al. Immediate hormonal therapy compared with observation after } \\
\text { radical prostatectomy and pelvic lymphadenectomy in men with node-positive prostate cancer. N Engl J } \\
\text { Med 1999;341:1781-8. }\end{array}$ & 460 \\
\hline 75 & $\begin{array}{l}\text { Terasaki PI, Cecka JM, Gjertson DW, et al. High survival rates of kidney transplants from spousal and living } \\
\text { unrelated donors. N Engl J Med 1995;333:333-6. }\end{array}$ & 460 \\
\hline
\end{tabular}


Table 1. The top 100 cited articles in urology (part 4 of 4)

\begin{tabular}{|c|c|c|}
\hline Rating & Article & $\begin{array}{l}\text { No. of } \\
\text { citations }\end{array}$ \\
\hline 76 & $\begin{array}{l}\text { Smith JR, Freije D, Carpten JD, et al. Major susceptibility locus for prostate cancer on chromosome } 1 \\
\text { suggested by a genome-wide search. Science 1996;274:1371-4. }\end{array}$ & 459 \\
\hline 77 & $\begin{array}{l}\text { Willett WC, Morris JS, Pressel S, et al. Prediagnositic serum selenium and risk of cancer. Lancet } \\
\text { 1983;2:130-4. }\end{array}$ & 458 \\
\hline 78 & $\begin{array}{l}\text { Oesterling JE, Chan DW, Epsetin JI, et al. Prostate specific antigen in the preoperative and postoperative } \\
\text { evaluation of localized prostatic cancer treated with radical prostatectomy. J Urol 1988;139:766-72. }\end{array}$ & 454 \\
\hline 79 & $\begin{array}{l}\text { Auger J, Kunstmann JM, Czyglik F, et al. Decline in semen quality among fertile men in Paris during the past } \\
20 \text { years. N Engl J Med 1995;332:281-5. }\end{array}$ & 454 \\
\hline 80 & $\begin{array}{l}\text { Dong JT, Lamb PW, Rinkerschaeffer CW, et al. KAl1, a metastasis suppressor gene for prostate cancer on } \\
\text { human chromosome 11P11.2. Science 1995;268:884-6. }\end{array}$ & 453 \\
\hline 81 & $\begin{array}{l}\text { Corey L, Adams HG, Brown ZA, et al. Genital herpes simplex virus infections: clinical manifestations, } \\
\text { course, and complications. Ann Intern Med 1983;98:958-72. }\end{array}$ & 452 \\
\hline 82 & McNeal JE, Kindrachuk RA, Freiha FS, et al. Patterns of progression in prostate cancer. Lancet 1986;1:60-3. & 448 \\
\hline 83 & $\begin{array}{l}\text { Partin AW, Pound CR, Clemens JQ, et al. Serum PSA after anatomic radical prostatectomy: the Johns } \\
\text { Hopkins experience after } 10 \text { years. Urol Clin North Am 1993;20:713-25. }\end{array}$ & 445 \\
\hline 84 & $\begin{array}{l}\text { Carani C, Qin K, Simoni M, et al. Effect of testosterone and estradiol in a man with aromatase deficiency. } \\
\text { N Engl J Med 1997;337:91-5. }\end{array}$ & 445 \\
\hline 85 & $\begin{array}{l}\text { Esrig D, Elmajian D, Groshen S, et al. Accumulation of nuclear P53 and tumor progression in bladder cancer. } \\
\text { N Engl J Med 1994;331:1259-64. }\end{array}$ & 442 \\
\hline 86 & $\begin{array}{l}\text { Stamey TA, Govan DE, Palmer JM. Localization and treatment of urinary tract infections: role of bactericidal } \\
\text { urine levels as opposed to serum levels. Medicine 1965;44:1-36. }\end{array}$ & 438 \\
\hline 87 & $\begin{array}{l}\text { Lapides J, Silber SJ, Lowe BS, et al. Clean, intermittent self-catheterization in treatment of urinary-tract } \\
\text { disease. J Urol 1972;107:458-61. }\end{array}$ & 436 \\
\hline 88 & $\begin{array}{l}\text { Roos NP, Wennberg JE, Malenka DJ, et al. Mortality and reoperation after open and transurethral resection } \\
\text { of the prostate for benign prostatic hyperplasia. N Engl J Med 1989;320:1120-4. }\end{array}$ & 433 \\
\hline 89 & $\begin{array}{l}\text { Chillon M, Casals T, Mercier B, et al. Mutations in the cystic fibrosis gene in patients with congenital } \\
\text { absence of the vas deferens. N Engl J Med 1995;332:1475-80. }\end{array}$ & 431 \\
\hline 90 & $\begin{array}{l}\text { Fleming C, Wasson JH, Albertsen PC, et al. A decision analysis of alternative treatment strategies for } \\
\text { clinically localized prostate cancer. JAMA 1993;269:2650-8. }\end{array}$ & 427 \\
\hline 91 & $\begin{array}{l}\text { Partin AW, Carter HB, Chan DW, et al. Prostate specific antigen in the staging of localized prostate cancer: } \\
\text { influence of tumor differentiation, tumor volume and benign hyperplasia. } J \text { Urol 1990;143:747-52. }\end{array}$ & 427 \\
\hline 92 & $\begin{array}{l}\text { Chaussy C, Schmiedt E, Jocham D, et al. First clinical experience with extracorporeally induced destruction } \\
\text { of kidney stones by shock waves. J Urol 1982;127:417-20. }\end{array}$ & 424 \\
\hline 93 & $\begin{array}{l}\text { Drach GW, Dretler S, Fair W, et al. Report of the United States cooperative study of extracorporeal shock } \\
\text { wave lithotripsy. J Urol 1986;135:1127-33. }\end{array}$ & 422 \\
\hline 94 & $\begin{array}{l}\text { Walsh PC, Lepor H, Eggleston JC. Radical prostatectomy with preservation of sexual function: anatomical } \\
\text { and pathological considerations. Prostate 1983;4:473-85. }\end{array}$ & 422 \\
\hline 95 & $\begin{array}{l}\text { Groth CG, Backman L, Morales JM, et al. Sirolimus (rapamycin)-based therapy in human renal } \\
\text { transplantation: Similar efficacy and different toxicity compared with cyclosporine. Transplantation } \\
\text { 1999;67:1036-42. }\end{array}$ & 422 \\
\hline 96 & $\begin{array}{l}\text { Balfour HH, Chace BA, Stapleton JT, et al. A randomized, placebo-controlled trial of oral acyclovir for the } \\
\text { prevention of cytomegalo virus disease in recipients of renal allografts. N Engl J Med 1989;320:1381-7. }\end{array}$ & 421 \\
\hline 97 & $\begin{array}{l}\text { Vincenti F, Kirkman R, Light S, et al. Interleukin-2-receptor blockade with daclizumab to prevent acute } \\
\text { rejection in renal transplantation. N Engl J Med 1998;338:161-5. }\end{array}$ & 420 \\
\hline 98 & Krane RJ, Goldstein I, Detejada IS. Impotence. N Engl J Med 1989;321:1648-59. & 420 \\
\hline 99 & $\begin{array}{l}\text { Garraway WM, Collins GN, Lee RJ. High prevalence of benign prostatic hyperplasia in the community. } \\
\text { Lancet 1991;338:469-71. }\end{array}$ & 419 \\
\hline 100 & $\begin{array}{l}\text { D'Amico AV, Whittington R, Malkowicz SB, et al. Biochemical outcome after radical prostatectomy, external } \\
\text { beam therapy, or interstitial therapy for clinically localized prostate cancer. JAMA 1998;280:969-74. }\end{array}$ & 418 \\
\hline
\end{tabular}


1992 at position 4, with the introduction of intracytoplasmic sperm injection for the treatment of infertility; and Goldstein and colleagues at position 6 , reporting on sildenafil for the treatment of erectile dysfunction. Men's health has been a topic generating much discussion in recent years and is represented by Feldman and coauthors in 1994 at position 1, with the results of the Massachusetts Male Aging Study, along with Sharpe and Skakkebaek in 1993 at position 10, with the effects of estrogen on men's fertility. The remaining

\begin{tabular}{lc}
$\begin{array}{l}\text { Table 2. Countries of origin of the top } \\
\text { articles in urology }\end{array}$ & No. of articles \\
\hline Country & 76 \\
United States & 9 \\
United Kingdom & 5 \\
Canada & 2 \\
Germany & 2 \\
France & 1 \\
Denmark & 1 \\
Sweden & 1 \\
Italy & 1 \\
Spain & 1 \\
Australia & 1 \\
Belgium & \\
\hline
\end{tabular}

\begin{tabular}{llc}
$\begin{array}{l}\text { Table 3. Institutions of origin with } 2 \text { or more } \\
\text { top-cited articles in urology }\end{array}$ & $\begin{array}{c}\text { No. of } \\
\text { articles }\end{array}$ \\
\hline Rank & \multicolumn{1}{c|}{ Institution } & 13 \\
\hline 1 & Johns Hopkins University & 5 \\
2 & Harvard University & 5 \\
3 & Stanford University & 5 \\
4 & University of California, Los Angeles & 4 \\
5 & Washington University & 3 \\
6 & Boston University & 3 \\
7 & National Institute of Health & 3 \\
8 & Indiana University & 2 \\
9 & Mayo clinic & 2 \\
10 & Memorial Sloan Kettering Cancer Center & 2 \\
11 & University of Michigan & 2 \\
12 & University of Minnesota & \\
\hline
\end{tabular}

Table 4. Most common first and second authors of the top 100 cited articles in urology

\begin{tabular}{lccc} 
Author & No. of articles & First author & Second author \\
\hline Partin A & 5 & 4 & 1 \\
Osterling J & 4 & 3 & 1 \\
Catalona W & 3 & 3 & - \\
Stamey T & 3 & 3 & - \\
Walsh P & 3 & 2 & 1 \\
\hline
\end{tabular}

2 articles within the top 10 positions reflect the development of important clinical tools in urology, namely, Racusen and colleagues in 1999 with the Banff histological classification of renal allograft rejection, and Barry and coworkers in 1992 with the AUA [American Urological Association] symptom index score for benign prostatic hyperplasia.

\begin{tabular}{|c|c|c|c|}
\hline Rank & Journal & $\begin{array}{l}\text { No. of } \\
\text { articles }\end{array}$ & $\begin{array}{c}\text { Impact } \\
\text { factor } \\
(2006)\end{array}$ \\
\hline 1 & New England Journal of Medicine & 30 & 51.296 \\
\hline 2 & Journal of Urology & 22 & 3.956 \\
\hline 3 & Lancet & 11 & 25.800 \\
\hline 4 & $\begin{array}{l}\text { Journal of the American Medical } \\
\text { Association }\end{array}$ & 10 & 23.175 \\
\hline 5 & Transplantation & 7 & 3.972 \\
\hline 6 & Science & 5 & 30.028 \\
\hline 7 & Annals of Internal Medicine & 5 & 14.780 \\
\hline 8 & $B M J$ & 2 & 9.245 \\
\hline 9 & Medicine & 2 & 5.167 \\
\hline 10 & Kidney International & 1 & 4.773 \\
\hline 11 & Urology & 1 & 2.130 \\
\hline 12 & Clinical Transplantation & 1 & 2.051 \\
\hline 13 & Neurology and Urodynamics & 1 & 2.688 \\
\hline 14 & Urologic Clinics of North America & 1 & 1.819 \\
\hline 15 & Prostate & 1 & 3.724 \\
\hline
\end{tabular}

Table 6. Study design of the top 100 cited articles in urology

\begin{tabular}{lc}
\hline Study design & No. of articles \\
\hline Observational & 56 \\
Randomized controlled trial & 14 \\
Basic science & 14 \\
Review article & 14 \\
Systematic review & 1 \\
Validation study & 1 \\
\hline
\end{tabular}

Table 7. Most common subspecialties represented in the top 100 cited articles in urology

\begin{tabular}{lc}
\hline Subspecialty & No. of articles \\
\hline Oncology & 51 \\
Transplantation & 20 \\
Sexual function/infertility & 13 \\
Voiding dysfunction & 10 \\
Urolithiasis & 2 \\
Infection/inflammation & 2 \\
Physiology/medicine & 1 \\
Surgery & 1 \\
\hline
\end{tabular}


The finding that most top-cited articles originated from the United States is not surprising and is consistent with the origin of citation classics in the fields of anesthesia ${ }^{2}$ and general surgery. ${ }^{4}$ The size of the American surgical community, its wealth and scientific output is larger than anywhere else worldwide, and does create bias in publication and citation rates. ${ }^{4}$ In addition, US authors tend to cite US articles, and US reviewers prefer US manuscripts. ${ }^{4}$

Our most frequently cited articles were published in highimpact journals. This is consistent with the finding that leading journals attract articles that are most likely to be the most highly cited publications, which in turn maintain the high impact factor of these journals. ${ }^{4}$ Further, one journal has actually published an open call for authors to cite more recent articles from journals with a high impact factor to raise the former's impact factor. ${ }^{9}$ This makes apparent the motivation and demonstrates one way in which citation counts may be manipulated.

Most of the articles retrieved were observational studies. This is contrary to many studies of the top-cited articles in other fields which report that review articles and methodological publications predominate. ${ }^{2}$ This has been explained by the need for authors to summarize and critically evaluate the rapidly expanding literature, but could also be a result of the restriction on the maximum number of allowed references of manuscripts enforced by many journals today. ${ }^{2}$ It is encouraging that original research predominated in our study. Urologists and clinicians in general need to continue to produce well-designed research studies, and readers need to continue to keep abreast of the most original and important scientific and medical advances.

One cannot assume that the top 100 cited articles presented here represent true "classics" or landmark articles owing to multiple sources of bias in the use of citation counts to rank articles. It should be noted that citation ranking is not intended to be a measure of quality, but rather a measure of recognition, that is, the absolute number of citations an article has accumulated cannot be used as the sole determinant of its importance. Time can have multiple effects on an article's citation ranking. With increasing age, each paper has more time in which to have been cited; therefore, the group of highest ranking articles can be dominated by some of the oldest. ${ }^{6}$ It has been reported that the true impact and eminence of an article often cannot be accurately assessed for at least 2 decades. ${ }^{2}$ Conversely, as time passes, even "landmark" papers may gradually become less cited because their content is absorbed into current knowledge without the need for referencing, as described by Garfield ${ }^{5}$ in 1987 - a process known as "obliteration by incorporation." Older publications may also become obsolete or simply forgotten. Papers that present novel techniques or methods that were once "popular" but have since ceased to be so can be overrepresented. ${ }^{4}$ Another criticism of citation analysis is that databases do not distinguish between positive or negative citations. ${ }^{2}$ A paper that is repeatedly cited because it was flawed or subsequently disproved could conceivably rank highly in a study such as ours; however, most readers probably would agree that it should not be included in the pantheon of landmark urological articles. Authors are supposed to acknowledge works that have influenced them the most, but this is not always the case. Both journal and author self-citation are prevalent sources of bias in citation analysis. ${ }^{9}$ Author and journal self-citations are not removed from citation counts or from the calculation of impact factors. As a result, both sources of bias may misrepresent the importance of individual articles, skew the calculation of journal impact factors and bias perceptions of the importance of a publication. ${ }^{9}$

Citations of original articles are generated when subsequent original articles reference that work; however, other types of papers such as reviews, meeting proceedings, abstracts and editorials also generate citations and are included in the Institute for Scientific Information database. ${ }^{1}$ Should citations from subsequent original articles be weighted differently? Incomplete citing and omission bias (bias toward not referencing competitors or sources contradictory to one's own results) are also problematic. ${ }^{2}$ Related to this, many journals, including The Journal of Urology, restrict the reference list to 20 original scientific publications, partly to control journal size but also to ensure that only the most recent and relevant papers are cited. ${ }^{10}$ This could lead to both incomplete and biased reference lists.

Our use of the 2006 impact factors to identify journals could be criticized since the citation counts of articles spanned the period of 1965 to present. To account for this we attempted to identify all urological journals from 1965 to 2007 using the Internet, consulting librarians and reviewing Gerharz and colleagues' book Classic Papers in Urology. Even with this technique, there is no doubt that articles related to urology exist in journals we did not search. A search for articles in journals of pathology, obstetrics and gynecology, cancer, pediatrics and further basic-science research, to name a few, would likely yield a different, if not more comprehensive, list. In addition, important historical articles were omitted because of the lack of electronic data before 1965 .

\section{Conclusion}

Citation analysis reveals useful and interesting information about scientific communications in our specialty. Observational studies and randomized controlled trials in oncology 
published in high-impact English urological or general medical journals constitute the most common type of highly cited publications in urology. Our findings reflect the attention that articles have received over the past 42 years, can be interpreted in many ways and should provoke informed debate. This information, along with current bibliometric indices, should assist urologists to optimize their time spent reading the medical literature and help guide future investigative efforts.

From the Department of Urologic Sciences, University of British Columbia, Vancouver, BC

This article has been peer reviewed.

Competing interests: None declared.

\section{References}

1. Bibliometrics [homepage]. Available: www.gslis.utexas.edu/ palmquis/courses/biblio.html (accessed 2009 June 30)
2. Baltussen $A$, Kindler CH. Citation classics in anesthetic journals. Anesth Analg 2004;98:443-51.

3. Dubin D, Hafner AW, Arndt KA. Citation classics in clinical dermatologic journals. Citation analysis, biomedical journals, and landmark articles, 1945-1990. Arch Dermatol 1993;129:1121-9.

4. Paladugu R, Schein $M$, Gardezi $S$, et al. One hundred citation classics in general surgical journals. World J Surg 2002;26:1099-105

5. Garfield E. 100 citation classics from the journal of the American Medical Association. JAMA 1987; 257:52-9.

6. Picknett T, Davis K. The 100 most-cited articles from JMB. J Mol Biol 1999;293:171-6.

7. Gerharz EW, Emberton M, $0^{\prime}$ Brien T. The top 100 papers in urology: Chapter 16. In: Classic papers in urology. Gerharz EW, Emberton M, O'Brien T, editors. Oxford (UK): Isis Medical Media; 1999. p. $339-61$.

8. Web of knowledge. ISI web of knowledge [homepage]. Available: http://isiwebofknow ledge.com (accessed 2009 June 30).

9. Gami AS, Montori VM, Wilczynski NL, et al. Author self-citation in the diabetes literature. CMAJ 2004:170:1925-7.

10. Smith JA Jr. References and citations-what do they really mean? J Urol 2007;178:2246.

Correspondence: Dr. Kiara Hennessey, Department of Urologic Sciences, Faculty of Medicine, University of British Columbia, Gordon \& Leslie Diamond Health Care Centre, Level 6, 2775 Laurel St., Vancouver BC V5Z 1M9; fax 604 875-4637; kkhennes@interchange.ubc.ca

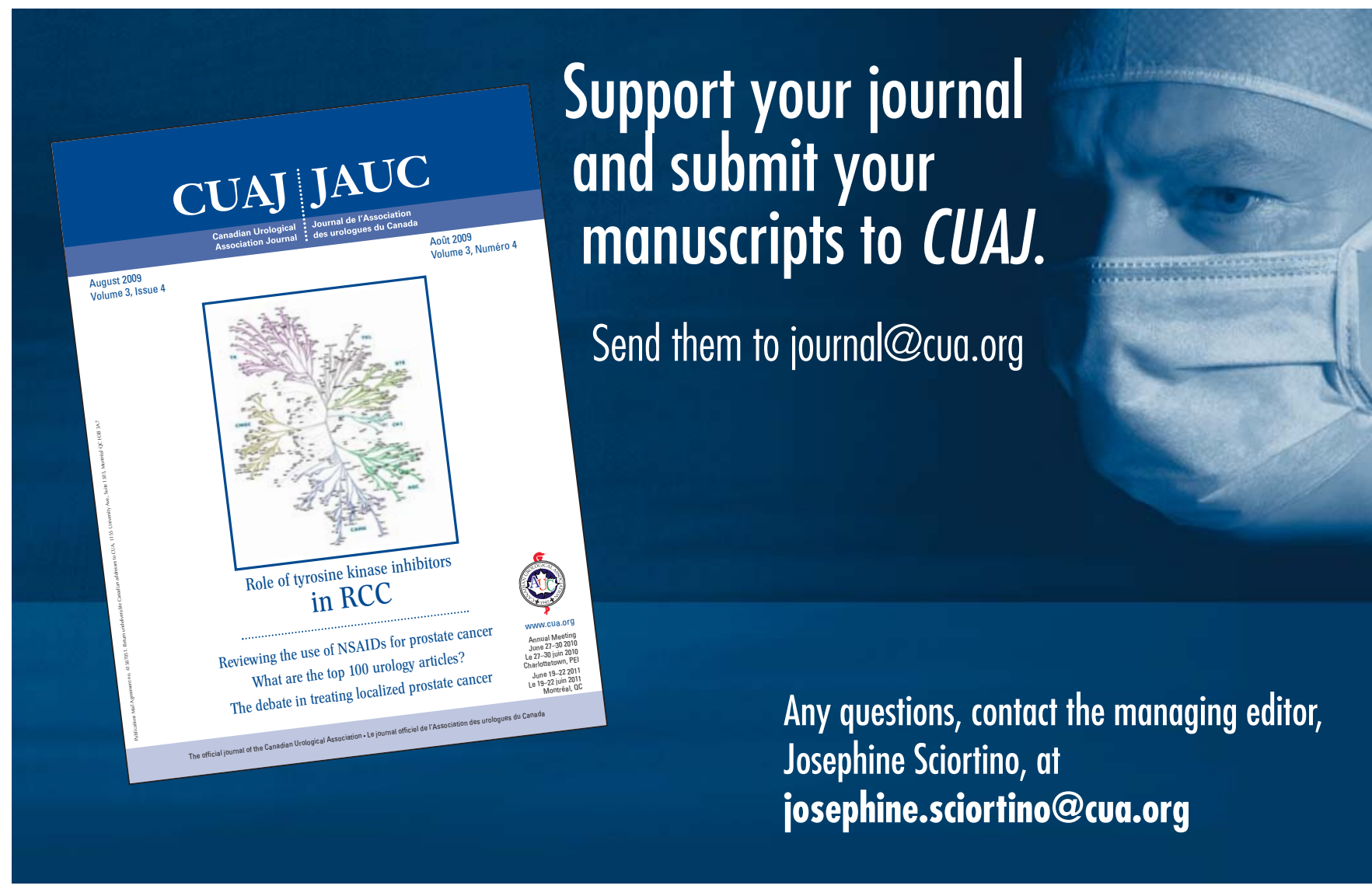

